\title{
Determination of Contours of Flooded Areas Due to Possible Accident of Zhinvali (Georgia) Earth Dam and Calculation of the Hydrodynamic Parameters of a Destructive Wave at a Dam
}

\author{
Givi Gavardashvili ${ }^{1, *}$, Tamriko Supatashvili ${ }^{1}$, Edward Kukhalashvili ${ }^{1}$, George Natroshvili ${ }^{1}$, \\ Irma Qufarashvili ${ }^{1}$, Inga Iremashvili ${ }^{1}$ and Konstantin Bziava ${ }^{1}$ \\ ${ }^{1}$ Tsotne Mirtskhulava Water Management Institute of Georgian Technical University, 0179, 60-b I. \\ Chavchavazde Ave., Tbilisi, Georgia
}

\begin{abstract}
Using theoretical and field studies, computer software programs (VOLNA-4, and MIKE-21,) and GIS technology, and taking into account the possible accident (destruction) of the Earth Dam with a height of 102 meters, the contours of the riverbed of flooded territories in riverbeds for rivers Aragvi and Mtkvari have been defined in the given article considering the configuration of the water-catchment basins of rivers.

By means of basic differential equations of hydraulics, geometrical dimensions of Zhinvali Earth Dam, hydrological basic parameters of the reservoir, and computer software, the basic hydrodynamic parameters of the destructive wave at the Zhinvali Earth Dam are calculated taking into account the time of flow movement.
\end{abstract}

Keywords: earth dam, accident, flood, risk, flooded territories.

\section{Introduction}

The reason for the disruption of hydraulic facilities, including Zhinvali Earth Dam (Georgia) may be natural calamities (earthquake, storm, mudflow, etc.), technogenic factors (corrosion and collapse of the building structures, violation of water intake regimes, etc.), as well as sabotage and terroristic acts and use of arms destructing dams during the war.

In case of disruption of a hazardous hydrodynamic plant, a 102-meter-high Zhinvali Earth Dam (Fig. 1) in our case, breakdown tsunami-type waves are formed potentially. The strength of the waves depends on the amount of water and wave velocity. Therefore, the hydrodynamic objects with great amount of water in their reservoirs and with a great difference between the heights of their head and tail races (high head), are hazardous in this respect.

\footnotetext{
*Corresponding author: givi_gava@yahoo.com
} 


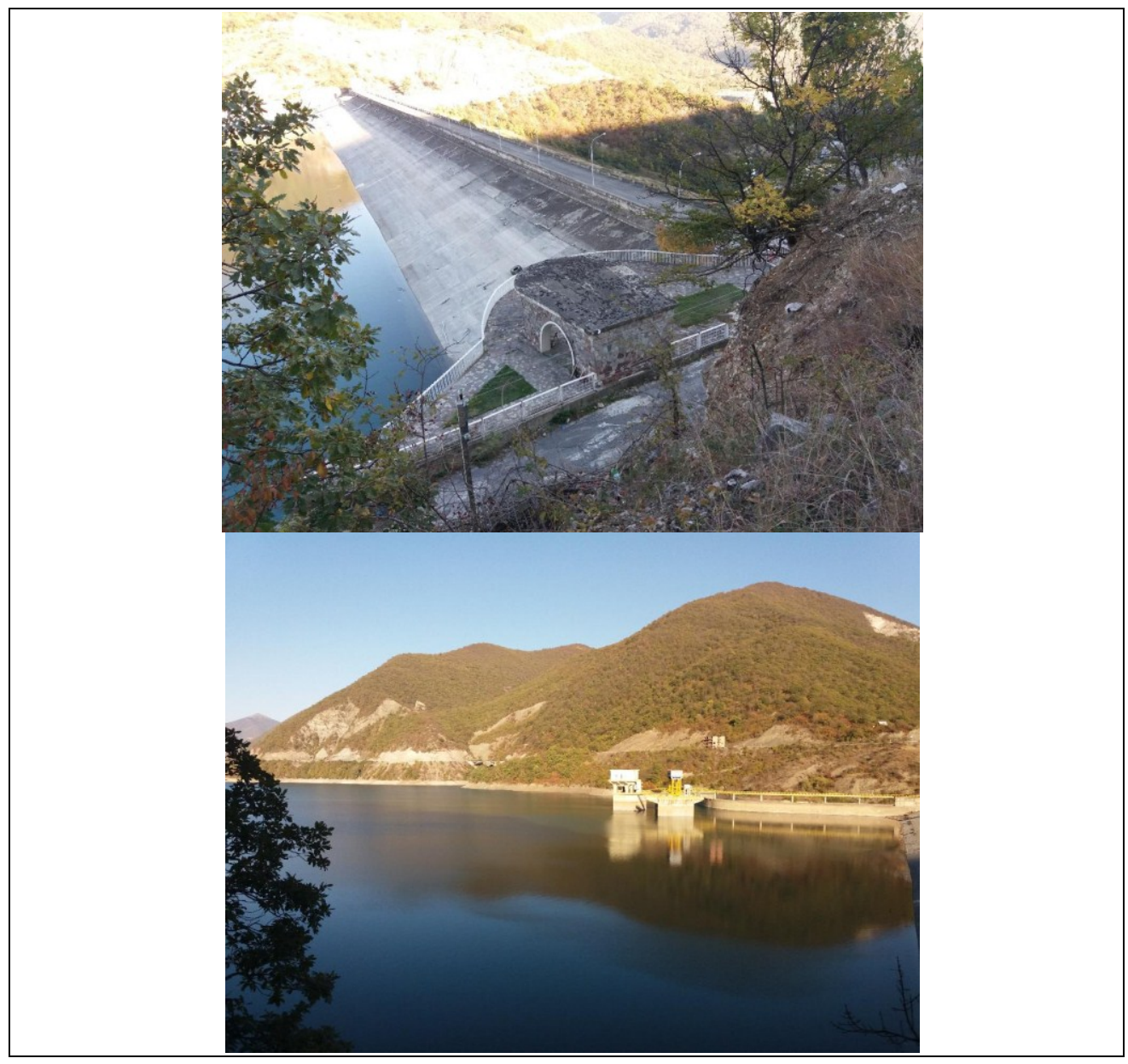

Fig. 1. General view of Zhinvali Earth Dam and reservoir

A breakdown wave and great water mass can overwhelm everything on their way: buildings, premises and agricultural plots, and may result in victims and great material losses [2].

The main function of Zhinvali Earth Dam is to protect the environment, economic objects and human life from the floods formed in the bed of the Aragvi River. However, in terms of incorrect exploitation of the dam and under the action of extreme natural phenomena (earthquake, catastrophic floods, etc.), Zhinvali Earth Dam itself may be a reason for a big catastrophe.

Following the category of a safety risk of a hydraulic facility (technological, environmental or social) and by considering a safety declaration of a facility owner, the terms of a dam operation must be observed by means of a safe operation and checks of the terms of no-failure operation of the plant units and all auxiliary facilities, buildings and equipment.

By considering the EU Directive on the assessment and management of flood risks in Georgia (January 1, 2012, http://www.slovakaid.sk/ ), a harmonization [2] and implementation mechanism must be incorporated in the legislation of the country what implies as follows:

- Developing a roadmap for harmonization and implementation of the EU Directive on the assessment and management of flood risks in the legislation of Georgia; 
- Developing a draft responsibility and actions Directive in the field of flood forecast and early warning for relevant ministries, what means:

$>$ The development of methodologies in the area of the flood risks and hydrological monitoring;

$>$ Developing the methodologies to draft the area of floods risks;

$>$ Developing the map of the zones of flood risks in the basins in the GIS system for the whole country;

$>$ Introducing modern hydrological models to predict floods;

$>$ Providing automated hydrological posts in the water catch basins of the rivers;

$>$ Training young experts in flood prediction issues, etc.

\section{THE METHODOLOGY TO CALCULATE HYDRODYNAMIC PARAMETERS OF TSUNAMI-LIKE WAVE}

With the aim to provide a computer imitation of possible technogenic catastrophes of Zhinvali Earth Dam, modified software VOLNA-4 and MIKE-4 algorithms were used and field studies of Zhinvali Dam were accomplished on February 10-27 (Fig. 2 and 3) what allows calculating the hydrodynamic parameters of the dam breakthrough wave in case of possible dam destruction, in particular: wave velocity, covered distance and more importantly, the sizes of the flooded area in relation to time.

The initial data were divided into two parts by us: the first is the permanent values and another is variable values. Permanent values consider the parameters not dependant on some or other condition; as for the variable values, they depend on flood, degree of dam destruction, etc.

The construction height of Zhinvali Earth Dam is $102 \mathrm{~m}$ and its effective height (water flooding height) is $96 \mathrm{~m}$. The dam width varies within $415 \mathrm{~m}$; the capacity of Zhinvali water reservoir is $520 \mathrm{mln} . \mathrm{m}^{3}$, while the water surface area is $733 \mathrm{mln} . \mathrm{m}^{3}$ [4].

In our case, in case of destruction of Zhinvali Earth Dam, destructing tsunami-like waves are formed potentially. The strength of the waves depends on the amount and velocity of water. Therefore, the hydrodynamic objects with great amount of water in their reservoirs and with a great difference between the heights of their head and tail races (high head), are hazardous in this respect.

A breakdown wave and great water mass can overwhelm everything on their way: buildings, premises and agricultural plots, and may result in victims and great material damage.
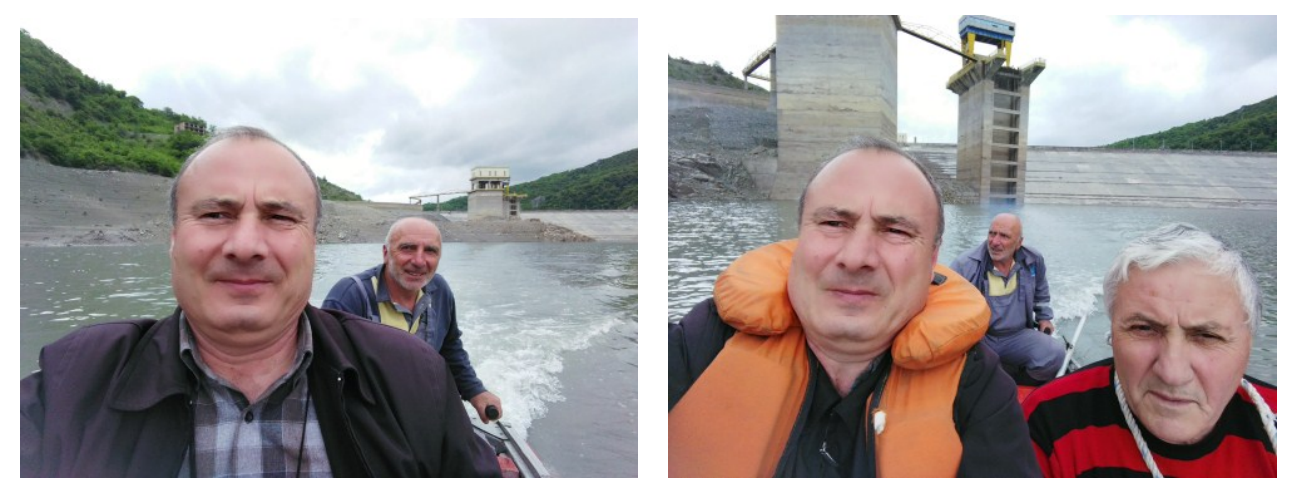

Fig. 2. Swimming on a motorboat in Zhinvali reservoir during the field studies 

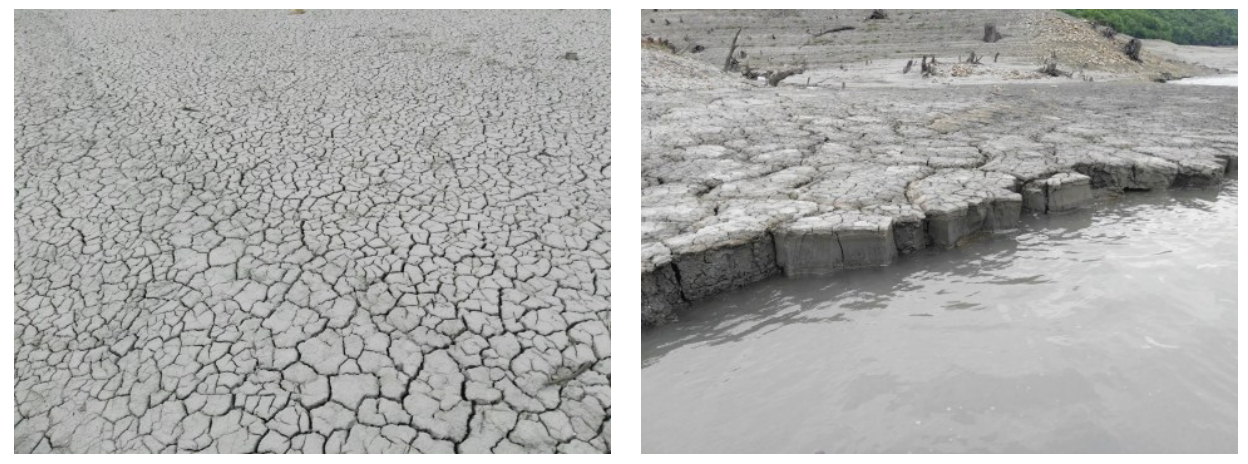

Fig. 3. General view of colloid and sandy material deposited in Zhinvali reservoir

Figure 4 shows a longitudinal profile of a tsunami-type wave formed in case of distruction of Zhinvali Earth Dam.

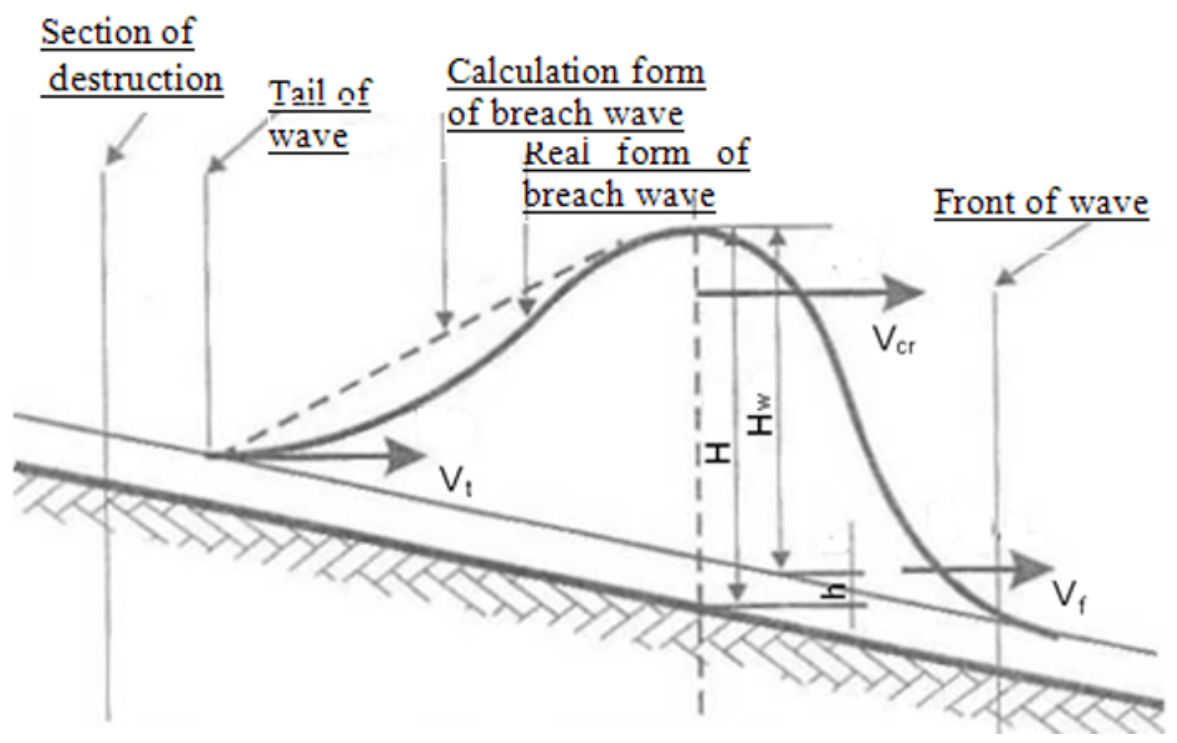

Fig. 4. Longitudinal profile of a tsunami-like wave

The volume of water in the reservoir $\left(W_{0}\right)$ was calculated with the following dependence $[2,5,5,10]$ :

$$
\left.W=\frac{H_{B} S_{B}}{3} \quad \text { (mln. } \mathrm{m}^{3}\right)
$$

Where $H_{B}$ is the water depth at the height of normal dam flooding (m); $S_{B}$ is the area of the water surface in the reservoir $\left(\mathrm{mln} . \mathrm{m}^{3}\right)$;

The width of river is taken from the topographic maps. As for the number of points, it must not exceed 3 points on the each side of the river axis, i.e. total of 6 points, and must cover the whole water catch area. In order to calculate the area of the flooded territory, the number of sections from the dam must not exceed 8 , with the distance between them to be plotted on a topographic map in advance.

The wave velocity (V) during the flood is calculated by the following formula in the tailrace of the facility [10]: 


$$
V=V_{0}\left(H_{1} / H_{0}\right)^{2 / 3}, \quad(\mathrm{~m} / \mathrm{sec})
$$

The degree of the dam destruction $\left(E_{\mathrm{p}}\right)$ was established with the following expression [64]:

$$
E_{p}=\frac{F_{B}}{F_{0}},
$$

Where $F_{B}$ is the area of the bank breach $\left(\mathrm{m}^{2}\right) ; F_{0}$ is the surface area $\left(\mathrm{m}^{2}\right)$.

Besides the above-mentioned, the algorithm considers: the height of the river bank edge $(\mathrm{m})$, number of sections along the river, distance between the sections $(\mathrm{km})$, width of the riverbed $(\mathrm{m})$, water current velocity in the riverbed $(\mathrm{m} / \mathrm{sec})$; width of the bed of the Nogha River (m), values of the river levels (m), etc.

Zhinvali water reservoir, with its Dam representing a structure with a fill clay is located in village Zhinvali, Dusheti Region. The construction height of the Dam is $102 \mathrm{~m}$ and its effective height (water flooding height) is $96 \mathrm{~m}$. The Dam width varies within $415 \mathrm{~m}$; the capacity of Zhinvali water reservoir is $520 \mathrm{mln} . \mathrm{m}^{3}$, while the water surface area is $733 \mathrm{mln} . \mathrm{m}^{3}$ (see Fig.5).

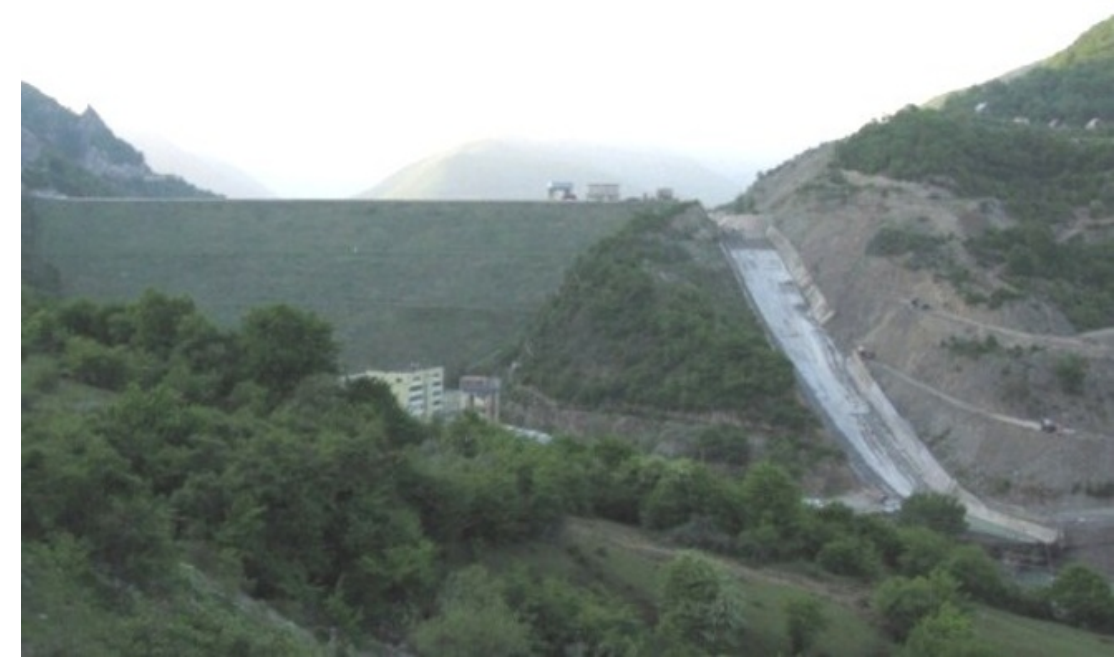

Fig. 5. View of Zhinvali Earth Dam from the tailrace

\section{IDENTIFYING THE CONTOURS OF THE AREAS FLOODED AS A RESULT OF A POSSIBLE ACCIDENT OF ZHINVALI EARTH DAM}

The number of sections from the Aragvi River to the Mtkvari River taken to predict the catastrophe of Zhinvali dam is 8 (Fig. 6).

The sections were taken in the following settled areas located at different distances from the dam, in particular, 1) village Misaktsieli - 30,0 km; 2) Avchala settlement - 35,0 km; 3) Dighomi (Shalikashvili) Bridge - 44,5 km; 4) Tamar Mepe (Chelyuskinites) Bridge 48,0 km; 5) Ortachala Bridge - 54,2 km; 6) new settlement of Rustavi - 74,0 km; 7) center of Rustavi - 77,0 km; and 8) end point of Rustavi - 80,0 km.

By using the theoretical and field studies, computer software (VOLNA - 4 and MIKE-21) and GIS technology [2-8,10,12], by considering a possible accident of a 102-meter-high Zhinvali Earthen Dam (Georgia) with 0.75 degree, the contours of the beds of the flooded areas in the Aragvi and Mtkvari Riverbeds were identified by considering the configuration of the water catch basins of the Rivers. The results of the calculation are given Table \#1. 
Detailed data about Zhinvali Dam are given in the Tables below (Tables 2 and 3) and the sizes of the flooded areas in the riverbed and in the adjacent areas are given in Figures 7-15.
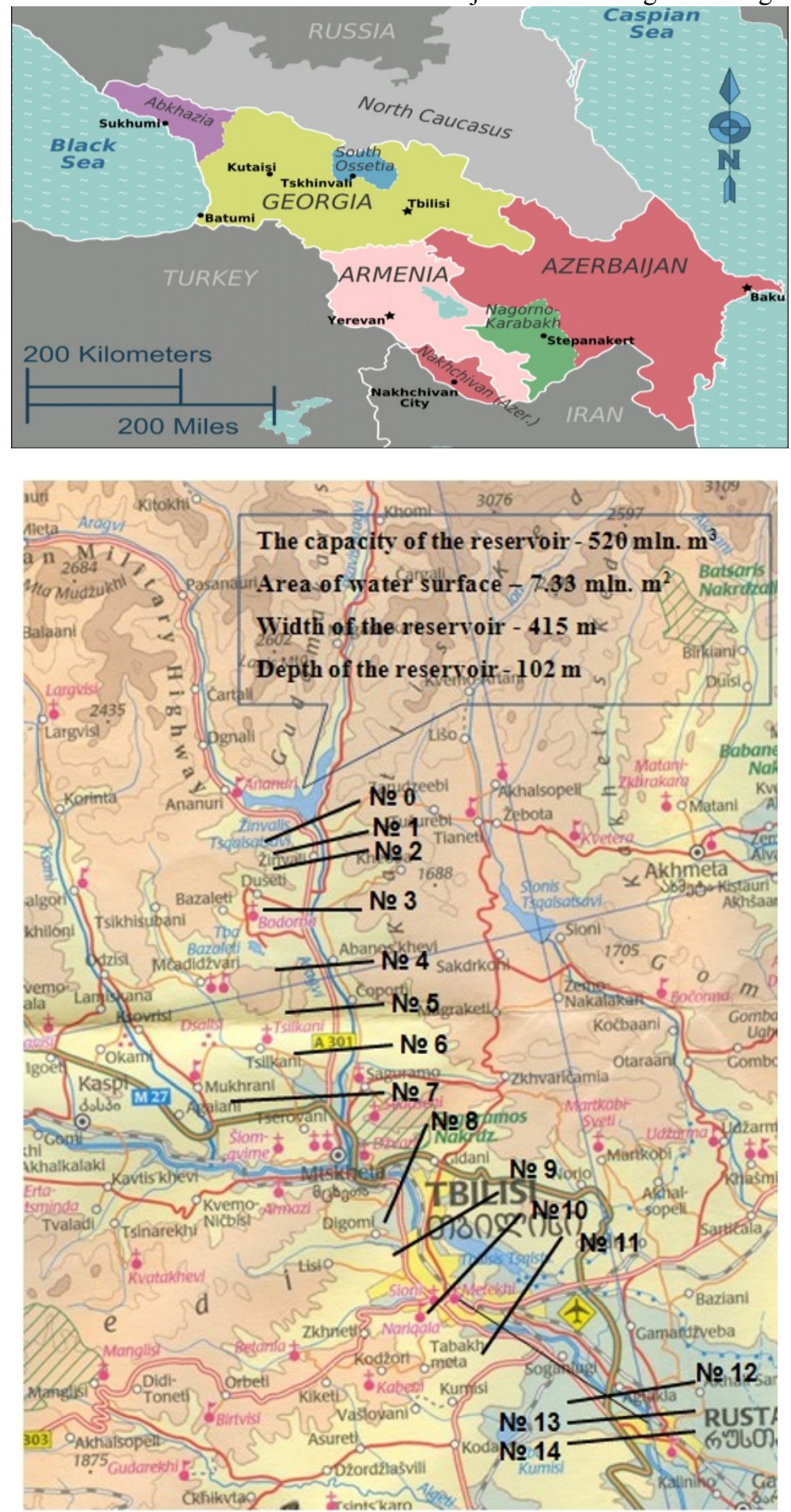

Fig. 6. Plan of location of design sections 
Table 1. Description: Zhinvali Dam (With Destruction Degree $\mathrm{E}_{3}=0,75$ )

Time: $29.02 .2020,14: 02: 40$

\begin{tabular}{|l|c|c|}
\hline \multicolumn{1}{|c|}{ Initial data of the hydrological system } & Unit of meas. & Number \\
\hline 1. Water reservoir capacity at standard flooding level (SFL) & $\mathrm{mln} . \mathrm{m}^{3}$ & 520 \\
\hline 2. Reservoir depth at SFL & $\mathrm{m}$ & 96 \\
\hline 3. Water surface area at SFL & $\mathrm{mln} . \mathrm{m}^{3}$ & 7,33 \\
\hline 4. dam width at SFL & $\mathrm{m}$ & 415 \\
\hline 5. River depth in the Dam tailrace & $\mathrm{m}$ & 1 \\
\hline 6. River width in the Dam tailrace & $\mathrm{m}$ & 25 \\
\hline 7. River velocity in Dam tailrace & $\mathrm{m} / \mathrm{sec}$ & 1 \\
\hline 8. Reservoir depth at the moment of the dam accident & $\mathrm{m}$ & 96 \\
\hline 9. Dam destruction degree & $\mathrm{m}$ & 0,75 \\
\hline 10. Height of the riverbed bank breach & $\mathrm{m}$ & 24 \\
\hline 11. Water standard flooding level in the reservoir & $\mathrm{m}$ & 816 \\
\hline 12. Number of lateral profiles in the riverbed & $\mathrm{pcs}$. & 8 \\
\hline
\end{tabular}

Table 2. Calculated numerical values

\begin{tabular}{|c|c|c|c|c|c|c|c|c|c|}
\hline Cross sections & $\begin{array}{c}\text { Unit of } \\
\text { meas. }\end{array}$ & $\begin{array}{c}\text { Secti } \\
\text { on } \\
\# 1\end{array}$ & $\begin{array}{c}\text { Secti } \\
\text { on } \\
\# 2\end{array}$ & $\begin{array}{c}\text { Secti } \\
\text { on } \\
\# 3\end{array}$ & $\begin{array}{c}\text { Secti } \\
\text { on } \\
\# 4\end{array}$ & $\begin{array}{c}\text { Secti } \\
\text { on } \\
\# 5\end{array}$ & \begin{tabular}{|c|} 
Secti \\
on \\
$\# 6$
\end{tabular} & $\begin{array}{c}\text { Secti } \\
\text { on } \\
\# 7\end{array}$ & $\begin{array}{c}\text { Secti } \\
\text { on } \\
\\
\# 8\end{array}$ \\
\hline 1 & 2 & 3 & 4 & 5 & 6 & 7 & 8 & 9 & 10 \\
\hline $\begin{array}{l}\text { Distance of } a i^{\text {th }} \text { section from the } \\
\text { Dam }\end{array}$ & $\mathrm{km}$ & 30 & 35 & 44,5 & 48 & 54,2 & 74 & 77 & 80 \\
\hline \multicolumn{10}{|l|}{ Specific current: } \\
\hline Water flooding level & $\mathrm{m}$ & 480 & 425 & 398 & 393 & 375 & 327 & 322,7 & 313 \\
\hline Depth & $\mathrm{m}$ & 1 & 3 & 2 & 2 & 1 & 2 & 1 & 1 \\
\hline Width & $\mathrm{m}$ & 70 & 60 & 80 & 82 & 80 & 150 & 100 & 93 \\
\hline Current velocity & $\mathrm{m} / \mathrm{sec}$ & 1 & 1 & 1 & 1 & 1 & 1 & 1 & 1 \\
\hline \multicolumn{10}{|l|}{ Left bank } \\
\hline Height of the river bank breach & $\mathrm{m}$ & 7 & 2 & 3 & 5 & 4 & 2,5 & 3 & 0,5 \\
\hline Width of the Nogha River bed & $\mathrm{m}$ & 50 & 10 & 50 & 20 & 20 & 5 & 5 & 40 \\
\hline Level \#1 & $\mathrm{m}$ & 490 & 435 & 402,5 & 400 & 383 & 330 & 327,5 & 315 \\
\hline $\begin{array}{l}\text { Distance from the river axis to } \\
\text { level \#1 }\end{array}$ & $\mathrm{m}$ & 137 & 50 & 440 & 71 & 180 & 100 & 60 & 225 \\
\hline Level \#2 & $\mathrm{m}$ & 520 & 440 & 405 & 405 & 385 & 340 & 330 & 320 \\
\hline $\begin{array}{l}\text { Distance from the river axis to } \\
\text { level \#2 }\end{array}$ & $\mathrm{m}$ & 687 & 70 & 670 & 371 & 280 & 125 & 1310 & 1295 \\
\hline Level \#3 & $\mathrm{m}$ & 680 & 490 & 410 & 415 & 388 & 350 & 332,5 & 322,5 \\
\hline $\begin{array}{l}\text { Distance from the river axis to } \\
\text { level \#3 }\end{array}$ & $\mathrm{m}$ & 2437 & 340 & 970 & 800 & 720 & 265 & 1610 & 1345 \\
\hline \multicolumn{10}{|l|}{ Right bank } \\
\hline Height of the river bank breach & $\mathrm{m}$ & 15 & 8 & 3 & 5 & 4 & 1 & 1 & 5 \\
\hline Width of the Nogha River bed & $\mathrm{m}$ & 30 & 25 & 50 & 20 & 100 & 300 & 300 & 50 \\
\hline Level \#1 & $\mathrm{m}$ & 520 & 435 & 402,5 & 410 & 380 & 330 & 325 & 340 \\
\hline $\begin{array}{l}\text { Distance from the river axis to } \\
\text { level \#1 }\end{array}$ & $\mathrm{m}$ & 912 & 60 & 840 & 90 & 510 & 525 & 750 & 440 \\
\hline Level \#2 & $\mathrm{m}$ & 600 & 445 & 405 & 415 & 385 & 340 & 337,5 & 350 \\
\hline $\begin{array}{l}\text { Distance from the river axis to } \\
\text { level \#2 }\end{array}$ & $\mathrm{m}$ & 1137 & 70 & 1680 & 200 & 660 & 600 & 900 & 570 \\
\hline \begin{tabular}{|l|} 
Level \#3 \\
\end{tabular} & $\mathrm{m}$ & 680 & 490 & 410 & 425 & 395 & 343 & 345 & 400 \\
\hline $\begin{array}{l}\text { Distance from the river axis to } \\
\text { level \#3 }\end{array}$ & $\mathrm{m}$ & 1637 & 540 & 2000 & 230 & 940 & 1300 & 1650 & 840 \\
\hline
\end{tabular}


Table 3. Hydrological values of the flooded area

\begin{tabular}{|c|c|c|c|c|c|c|c|c|c|c|}
\hline Dam destruction parameters & \begin{tabular}{|c|}
$\begin{array}{c}\text { Unit } \\
\text { of } \\
\text { meas }\end{array}$ \\
\end{tabular} & $\begin{array}{c}\text { Sectio } \\
\mathbf{n} \\
\# 0\end{array}$ & $\begin{array}{c}\text { Sectio } \\
\text { n } \\
\# 1\end{array}$ & $\begin{array}{c}\text { Sectio } \\
n \\
\# 2\end{array}$ & $\begin{array}{c}\text { Sectio } \\
\text { n } \\
\# 3\end{array}$ & $\begin{array}{c}\text { Sectio } \\
n \\
\# 4\end{array}$ & $\begin{array}{c}\text { Sectio } \\
n \\
\# 5\end{array}$ & $\begin{array}{c}\text { Sectio } \\
\mathrm{n} \\
\# 6\end{array}$ & $\begin{array}{c}\text { Secti } \\
\text { on } \\
\# 7\end{array}$ & $\begin{array}{c}\text { Sectio } \\
\mathbf{n} \\
\# 8\end{array}$ \\
\hline $\begin{array}{l}\text { Distance of the section from the } \\
\text { hydrological station }\end{array}$ & $\mathrm{km}$ & 0 & 30 & 35 & 44,5 & 48 & 54,2 & 74 & 77 & 80 \\
\hline Water peak discharge in the section & \begin{tabular}{|c|} 
thous \\
$\dot{\mathrm{m}} / \mathrm{se}$ \\
$\mathrm{c}$
\end{tabular} & 137 & 24,4 & 21,9 & 18,12 & 17,2 & 15,59 & 12,32 & 11,84 & 11,5 \\
\hline \multicolumn{11}{|l|}{ Time: } \\
\hline Of wave front descending & $\min$ & 0 & 47,1 & 57,8 & 76,9 & 90,9 & 108,5 & 175,5 & 186,7 & 201 \\
\hline Of wave descending & $\min$ & 0 & 80,2 & 99,1 & 143,4 & 158 & 180,7 & 288,7 & 301,9 & 314,8 \\
\hline Wave tail descending & $\min$ & 149 & 649 & 732 & 890,4 & 949 & 1052 & 1382 & 1432 & 1482 \\
\hline Of flooding & $\min$ & 149 & 602 & 674 & 813,5 & 858 & 943,6 & 1207 & 1245 & 1281 \\
\hline Maximum flow velocity & $\mathrm{m} / \mathrm{sec}$ & 18,7 & 11,2 & 14,1 & 5,03 & 9,53 & 6,77 & 6,86 & 4,91 & 5,26 \\
\hline Wave height & $\mathrm{m}$ & 56,6 & 18,6 & 29,7 & 6,15 & 14,8 & 8,29 & 7,88 & 4,88 & 5,41 \\
\hline Maximum flooding depth & $\mathrm{m}$ & 57,6 & 19,6 & 32,7 & 8,15 & 16,8 & 9,29 & 9,88 & 5,88 & 6,41 \\
\hline Maximum flooding level & $\mathrm{m}$ & 778 & 499 & 455 & 404,2 & 408 & 383,3 & 334,9 & 327,6 & 318,4 \\
\hline \multicolumn{11}{|l|}{ Maximum flow height: } \\
\hline On the left bank of the river & $\mathrm{m}$ & 152 & 294 & 862 & 591,6 & 614 & 211,7 & 112,2 & 97,83 & 955,8 \\
\hline On the right bank of the river & $\mathrm{m}$ & 152 & 185 & 524 & 1394 & 84,8 & 608,8 & 561,6 & 780,9 & 103 \\
\hline
\end{tabular}

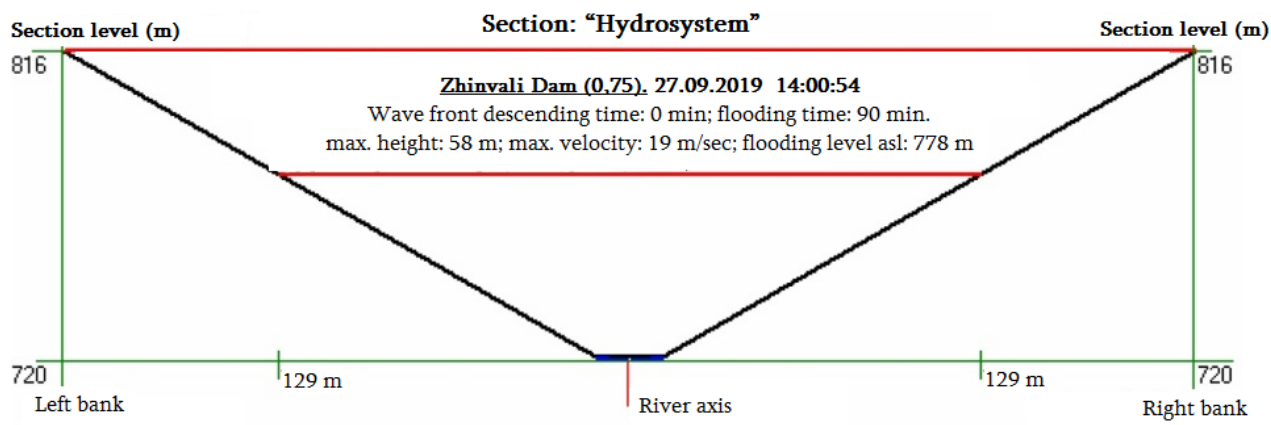

Fig. 7. Section of Hydrosystem

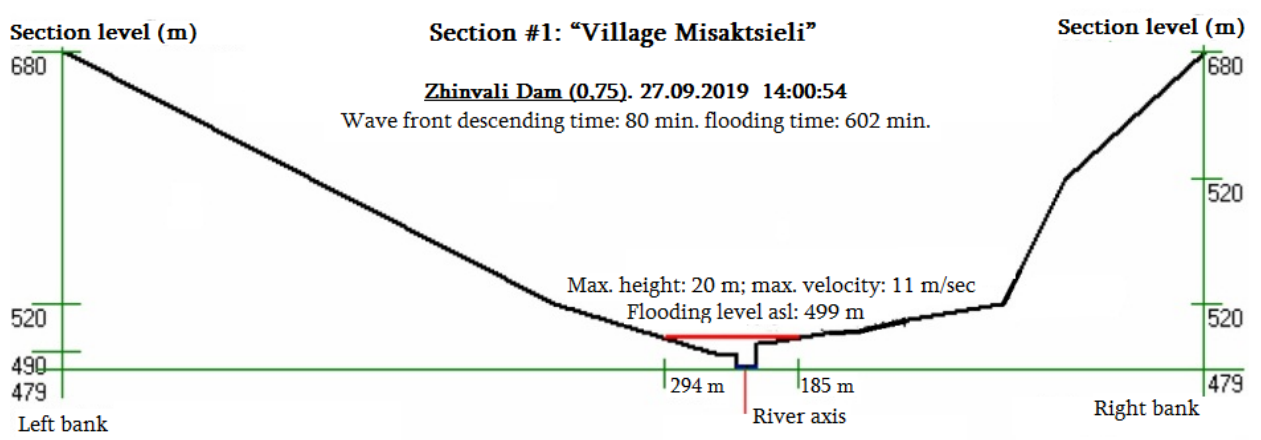

Fig. 8. Section \#1, Village Micaktsieli 


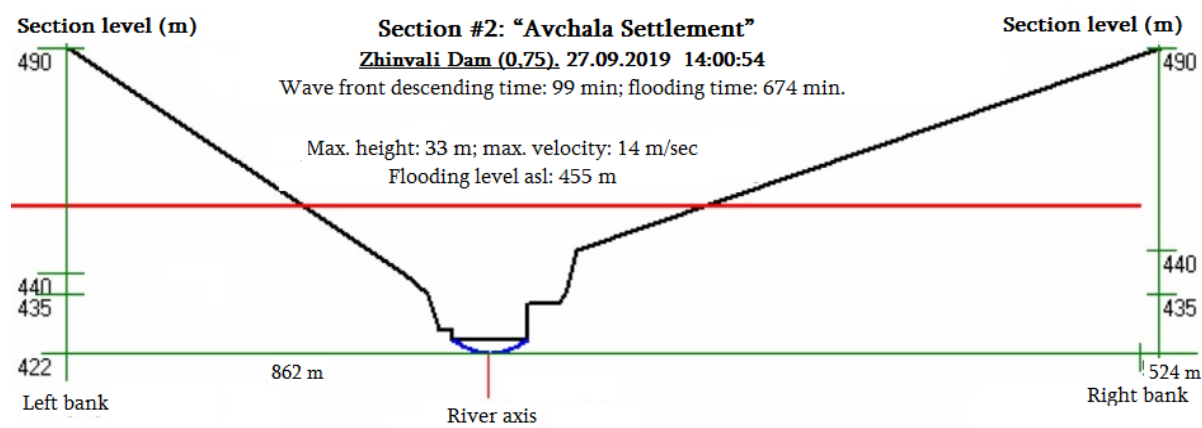

Fig. 9. Section \#2, Village Avchala Settlement

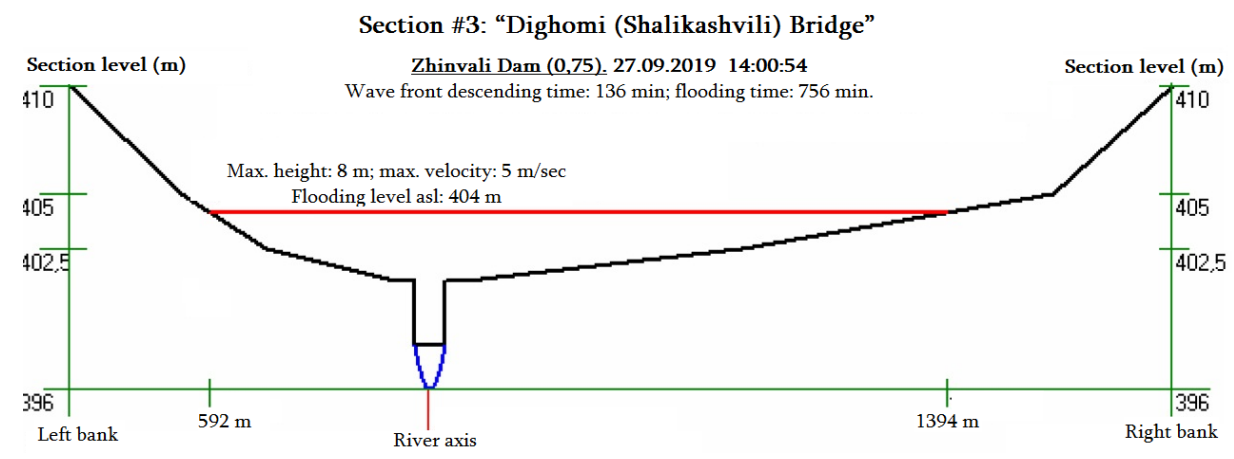

Fig. 10. Section \#3, Digomi (Shalikashvili Bridge)

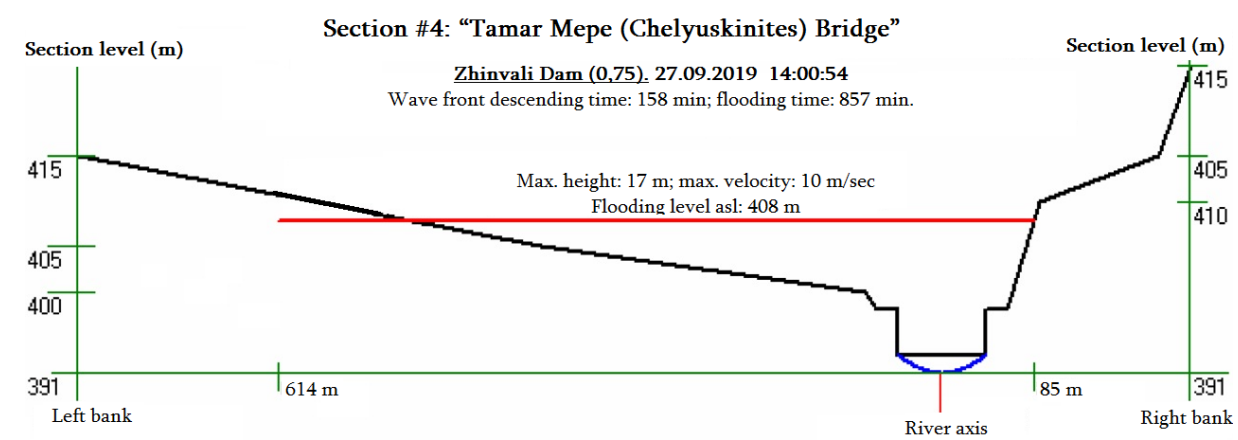

Fig. 11. Section \#4, Tamar Mepe (Chelyuskintses) Bridge

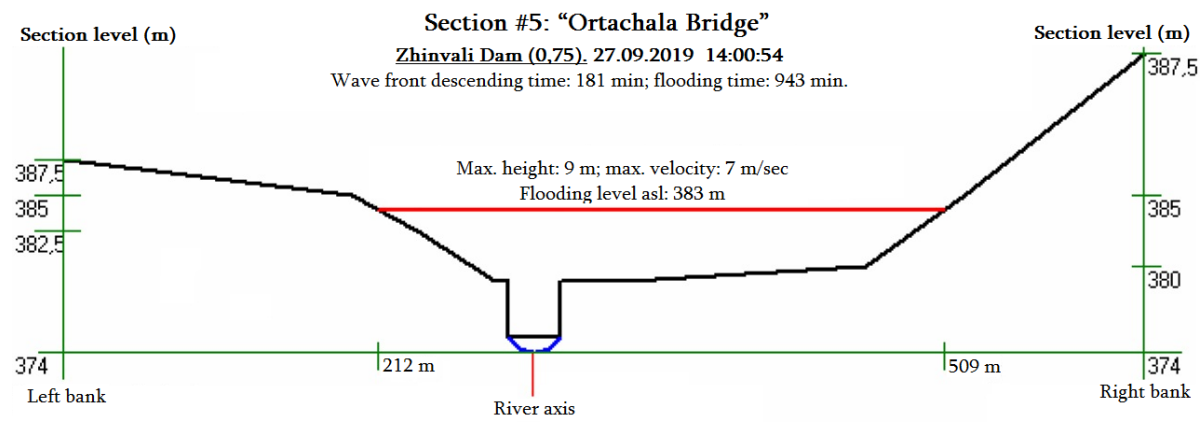

Fig. 12. Section \#5, Tamar Ortachala Bridge 


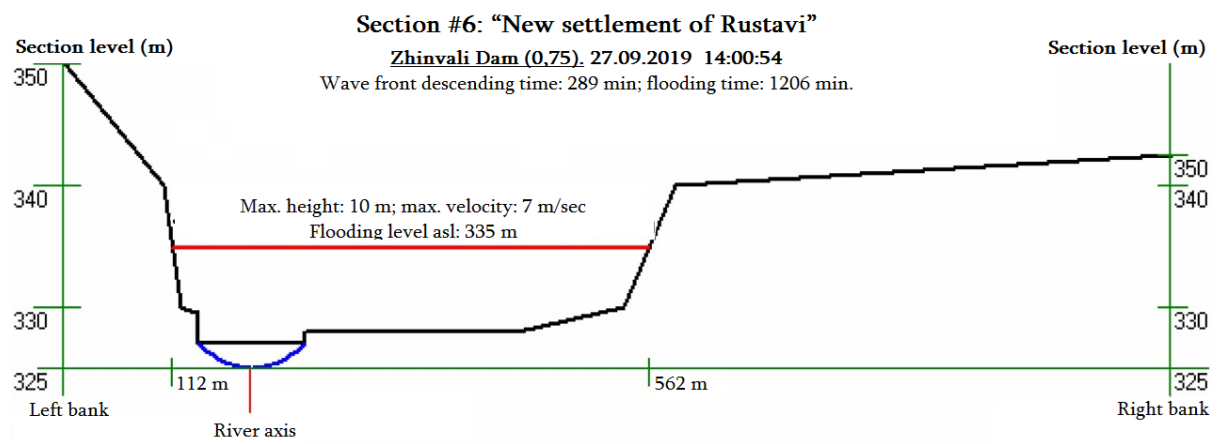

Fig. 13. Section \#6, New settlement of Rustavi

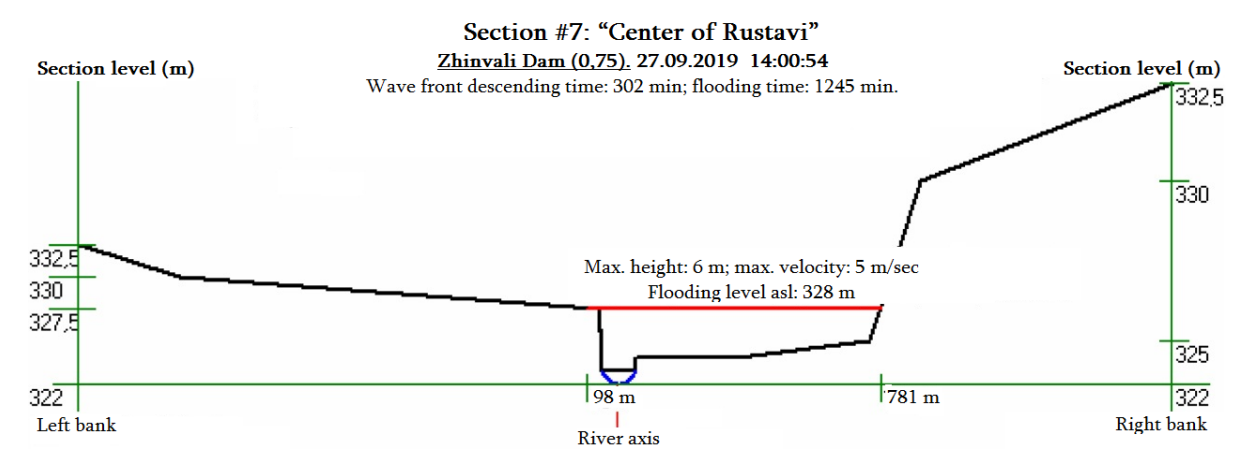

Fig. 14. Section \#7, Center of Rustavi

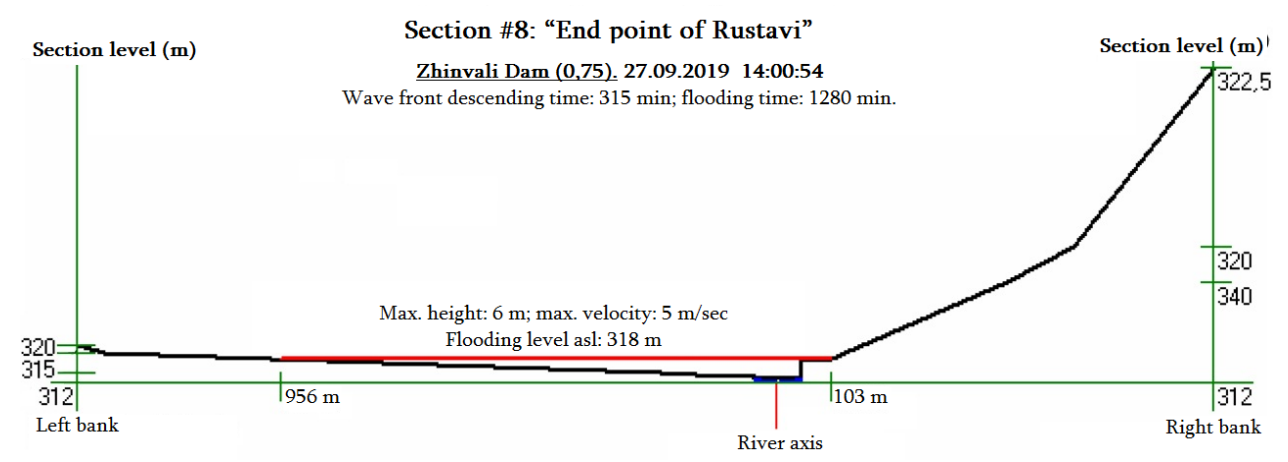

Fig. 15. Section \#8, End point of Rustavi

As for the hydrodynamic data of a tsunami-type wave formed following the accident with 0.75 destruction degree of Zhinvali Dam by considering the time factor, the geometrical data of the flooded area are given in Table \#4. 
Table 4. Geometric data of the flooded area

\begin{tabular}{|c|c|c|c|c|c|c|}
\hline \multirow[t]{2}{*}{ \# } & \multirow[t]{2}{*}{ Section } & \multirow[t]{2}{*}{$\begin{array}{c}\text { Tsunami } \\
\text { wave motio } \\
\text { time (min) }\end{array}$} & \multicolumn{2}{|c|}{\begin{tabular}{|c|}
$\begin{array}{c}\text { Width of the flooded area } \\
\text { from the center of } \\
\text { symmetry of the riverbed } \\
\text { (m) }\end{array}$ \\
\end{tabular}} & \multirow[t]{2}{*}{$\begin{array}{c}\text { Height of } \\
\text { tsunami } \\
\text { wave (m) }\end{array}$} & \multirow[t]{2}{*}{$\begin{array}{l}\text { Velocity of } \\
\text { tsunami } \\
\text { wave } \\
\text { (m/sec) }\end{array}$} \\
\hline & & & Right & Left & & \\
\hline 1 & Village Misaktsieli & 47,1 & 322 & 319 & 21 & 11 \\
\hline 2 & Avchala settlement & 57,74 & \multicolumn{4}{|c|}{ The canyon gets flooded on both sides } \\
\hline 3 & $\begin{array}{l}\text { Dighomi (Shalikashvili) } \\
\text { Bridge }\end{array}$ & 76,34 & 1603 & 649 & 9 & 5 \\
\hline 4 & $\begin{array}{l}\text { Tamar Mepe } \\
\text { (Chelyuskinites) Bridge }\end{array}$ & 90,1 & 715 & 88 & 18 & 10 \\
\hline 5 & Ortachala Bridge & 107,0 & 629 & 239 & 10 & 7 \\
\hline 6 & $\begin{array}{l}\text { New settlement of } \\
\text { Rustavi }\end{array}$ & 172,6 & 570 & 115 & 11 & 7 \\
\hline 7 & Center of Rustavi & 183,3 & 786 & 293 & 6 & 5 \\
\hline 8 & End point of Rustavi & 197,3 & 110 & 1055 & 7 & 5 \\
\hline
\end{tabular}

Thus, based on the field, theoretical and experimental studies, the principal hydrodynamic properties of Tsunami wave formed as a result of possible destruction of Zhinvali Earth Dam were identified by considering the relevant time factor and the geometry of the flooded area was determined as well.

The risk zones of the flooded areas were specified and the norms of behavior for the population in the state of emergency were developed [2,9].

\section{Conclusions}

Under the financial support of Grant Project \# FR17_615 "Assessment of safety risks of vulnerable infrastructure during the formation of expected catastrophes", based on the complex studies accomplished during the field scientific expeditions for Zhinvali Earth Dam in 2019-2020, we may draw the following conclusions:

1. As a result of the studies accomplished in Zhinvali reservoir, the statistical material was processed, which allows specifying the volume of the solid drift deposited in the headrace of the Dam and minimum useful water capacity;

2. The samples of colloid fraction were taken from the reservoir area and a chemical analysis of the suspension was provided with the aim to use it for commercial purposes;

3. Based on the scientific studies in the tail and head races of Zhinvali Earth Dam, a longitudinal profile of a tsunami-type wave formed as a result of the possible dam destruction was determined by calculating relevant hydrodynamic parameters;

4. For the case of a 0,75\% destruction degree of 102-meter-high Zhinvali Earth Dam, by using a mathematical model (VOLNA - 4 and MIKE-21) and GIS-technology, the contours of the riverbed of flooded territories in riverbeds for rivers Aragvi and Mtkvari have been defined by considering the configuration of the water catch basins of the rivers.

5. Based on the obtained data, the risk zones of the flooded areas were specified and the norms of behavior for the population in the state of emergency were developed.

\section{Acknowledgment}

The research was financial supported by Shota Rustaveli National Science Foundation of Georgia, Grant Project \# FR17_615 "Theoretical research of vulnerable infrastructure security risk during formation of predictable disasters". 


\section{References}

1. B.M. Ayyub, Risk Analysis Engineering and Economics. A CRC Press Company. Boca Raton, London, New York, Washington, D.C., 571 p. (2003)

2. Determination of the risk zones of flooded areas and evaluation of the rules of population behavior in an emergency situation in a case of potential accident of Zhinvali earth dam. Grant Project Leader: Givi Gavardashvili - Doctor of Technical Sciences, Professor. Tbilisi, Public House „Sachino”, 63 p. (2019)

3. G.V. Gavardashvili - Forecasting the Security of the Local People in Village Nakra of Mestia Region (Georgia) Against Floods and Mudflows. // Environments, ITS, www. itspoa. com/ jurnal/envi, UK, pp. 13-24 (2018)

4. G. Gavardashvili, E. Kukhalashvili, T. Supatashvili, G. Natroshvili, I. Qufarashvili, K. Bziava. The Calculation of Maximal and Average Speed of Debris Flow Formed as a Result of Outstretched Water Wave on the Land Dam of Zhinvali. International Conference on Construction and Environmental Engineering. WASET, Barcelona, Spain, pp. 1029- 1032 (2019)

5. G. Gavardashvili, E. Kukhalashvili, T. Supatashvili, G. Natroshvili, I. Qufarashvili, K. Bziava. The Ecological Awareness Level Arising of the Population Living in the Flood Risk Zone in case of Possible Accident of Zhinvali Land Dam and Designing Precautionary Measures. XIII International Conference on Environmental, Biological, Ecological Sciences and Engineering. WASET, Rome, Italy, pp. 755- 758 (2019)

6. Ts.E. Mirtskhulava. Hazards and Risk (at some water and other systems. Types, Analysis, Assessment). 2 Books. Tbilisi, "Metsniereba", 807 p. (in Russian) (2003)

7. Mike 21 Flow Model. Hints and recommendations in applications with significant flooding and drying [interaktyvus] [žiūrèta 2012-12-10]. Prieiga per internetą: $<$ http://www.dhigroup. com/ upload/dhisoftwarearchive/papersanddocs/hydrodynamics/MIKE21SignificantFlodry Guidelines.

8. O.G. Natishvili, G.V. Gavardashvili. Dynamics of Gully-Formation by Considering the Wave Motion of Flow. American Scientific Research Journal for Engineering, Technology and Sciences (ASRJEST), Vol 55, \#1, pp. 17-26. http://asrjtsjournal.org/index.php/American Scientific_Journal/issue/view/81 (2019)

9. A. Prangishvili, N. Bochorisvili, O. Lanchava. Life Safety - Emergensy Management and Sivil Defense (in Georgian). Tbilisi, 638 p. (2011)

10. S.K. Shoigu. Operative prediction of the engineering situation in emergency situations (Book 2), Moscow, 176 p. (1998)

11. D.V. Shterenlikht. Hydraulic. Energoatomizdat, Moscow, 494 p. (1984)

12. V. Urbanavičius. Kaunas's Impact on Hydrodynamics of the Neman River. Alexander Stulginski University. Kaunas, Lithuania, 54 p. (2013) 